\title{
Intellectual culture of the modern manager
}

\author{
I. Donnikova, V. Paulava \\ National University «Odessa Maritime Academy», Odessa, Ukraine \\ Corresponding authors. E-mail: donnikova_iran@ukr.net,os.pavlova88@gmail.com
}

Paper received 03.11.19; Accepted for publication 16.11.19.

\section{https://doi.org/10.31174/SEND-PP2019-209VII86-05}

Abstract. Analyzes the modern intellectual culture as a condition of civil society. The necessity of a change of mind and knowledge of educational reform for the formation of a new intellectual culture. Violated the possibility of combining training with the development of their managers as members of civil society. This is possible provided education orientation intellectual culture as part of the culture of individual students. It is emphasized that culture in any of its forms is aimed at protection and human development, supporting its harmony with the world. Management is transformed into a management culture if it helps man-preserving management, attached to the process of self-organization of human life and society. Transformation of values and organization management is impossible without intellectual culture. Grafting intellectual capital is due to the creation of cultural (value) in the context of education, humanitarian educational practices centered - a person who creates, which is able to direct their knowledge and action on selfdevelopment in organic unity with the world. Intellectual culture of the modern manager formed in accordance with the educational practices through an efficient transfer of educational and professional skills.

Keywords: culture management, intellectual culture, co-generative knowledge, humanitarian educational technology, transfer fundamental knowledge, transfer technology frame-learning.

Introduction. The democratic processes in Ukraine aimed at spreading and improving the system of selfmanagement and civil society. They are accompanied by changes in social institutions, forms of governance and implementing of different activities. However, the democratization of the society is impossible without changing the way people think, and therefore without reforming education. At present in Ukraine, education should prepare young people not only for working in the professional sphere, but also for active participation in public life, for creation of modern forms of social management. Of course, education has its own goals and objectives related to the development of human abilities that are defined by the general concept of "education". This raises the question of how professional training can be combined with the development of young people as members of civil society. In our view, the issue of new intellectual culture that determines the specificity of human thought, understanding as their own social role, and opportunities in the complex world, should be raised. We will specify the problem and analyze it in the context of contemporary intellectual culture of the modern manager evolvement. In particular, we will consider the following questions: factors that determine the culture of management and corporate culture; concept of modern intellectual culture in the context of university education; educational technologies aimed at the establishment of the modern intellectual culture manager.

Short review of the publications on the subject. The term "culture of management" in the modern study is many-valued and usually revealed through such things as "organizational culture", "corporate culture" etc. Typically, research of management culture starts with the broader context, namely, to disclose the content of the concepts of "culture", "national (ethnic) culture" to clarify the differences between subcultures, various social associations and organizations. Effective management is an appropriate analysis of organizational culture. Researchers distinguish two main management strategies - negotiation (to maintain order and continuity) and conversion (changing and violations of existing models). It emphasizes that the choice of strategy is determined by the context, the internal and external environment [1, p. 96].

Scientific interest in the study of connection between culture and management is explained by the proliferation of such types of management as a socio-ethical and stabilization [2, pp. 331-332]. Social and ethical management allows a self-government in an organization, provides an advanced incentive system of motivation, taking into account the diversity of employee labor values and universal values. The Stabilization management aimed at keeping the organization within existing boundaries, or preventing the transition into the zone of the uncontrolled state [2, p. 332]. One of the main objectives of social and ethical management is preventing harm, danger for the organization, and society. As for the management of complex social processes only legal regulation is not sufficient, the problem of creating a culture of management is also updated.

In the so-called "anthropological paradigm" organizations are described as well as national cultures. The Organizational culture is defined and limited by cultural group settings (language, borders, ideology) and regulatory criteria. Thus, the culture is not separated from the organization, it is difficult to manipulate and change it. It determines what the group notes and how the environment is controlled [1, p.93].

The authors of the book "Cultures and organizations: software of the mind" defines culture as " the collective programming of the mind that distinguishes the members of one group or category of people from others» [3, p.6]. The basis of culture is the values and morals, and culture is the unwritten book with rules of the social game that is passed on to newcomers by its members, nesting itself in their minds [3, p.26]. Despite the common use of the concept, national and organizational cultures are not identical. The authors emphasize that " the difference between national and organizational cultures is based on their different mix of values and practices». If the national culture is part of the mental program acquired in the human family, in a social environment and at school, it contains the most basic values. However, the organizational culture appears when a person becomes an adult 
and starts working at an organization with its certain values. That organizational culture is more professional $[3, \mathrm{p}$. 346]. That is why cross-cultural management should take into account cultural differences of its members, and to prepare them to work in multicultural organizations. Finally, each employee determines the degree of immersion in their own organizational culture.

Thus, the concept of "corporate culture" and "culture of management" focus on the "human factor" of management at the individual level, cultural differences of people - members of an organization. Nevertheless, solving the problem is complicated by the fact that it turns ontological incompatibility of two levels - the culture as a whole and its parts (organizational cultures and individual cultures). Moreover, the concept of organizational culture (and culture management) too tightly tied to the economic context. This leads to the fact that organizational culture becomes a kind of corporate culture that its content can deny the dominant culture, thus producing a conflict with it. However, the differentiation and institutionalization should not threaten culture, whose main task is forming landmarks promoting self-determination rights and identification with a certain social community. All cultures are similar in structure, with moral and evaluative components and non-conflict on its own core [4, p. 32].

Thus, the purpose of the article is to reveal the features of the intellectual culture of a modern manager.

Presenting main material. So, let us first define the concept of culture. In our publications, we emphasized that understanding culture is not possible outside of man and human existence [5, p. 64]. The study of any species and forms of culture should begin with the ontological and methodological assumptions of the unity of culture and people, it has to organize, build, deploy their living world, to represent its essence, and man invents culture, through which the world is created [5, p. 67]. In general, culture is a way of self-organization of human life. Since man is inherently creative and destructive by nature, basic purpose of culture is to promote human manifestation of a person, even if the understanding of what is human, by the very same person is constantly being changed. Some restraints mechanisms of human self-destruction are created, kept and constantly updated in the culture [5, p.68].

Culture is co-generative in essence, that aims to protect and develop human support for their harmony with the world. Creativity as co-generativity is characterized by any cultural phenomena that become defined as "cultural", and culture of management is not an exception. If the management of their own rules and purposes becomes a cultural force that helps man-preserving management, then it is transformed into a culture of management. Such a transformation of values is not possible without a culture of thinking in a broader meaning - intellectual culture.

The complex reality of late twentieth - early twentyfirst centuries demands new requirements to thinking, knowledge and management of human activity. Rethinking of development strategies of civilization needs a new intellectual culture, innovative forms of institutionalization and distribution (including education) and a new generation of intellectuals who have co-generative thinking, constructive knowledge, co-productive knowledge and practices.
The modern studies have linked the phenomenon of intellectual culture with innovations and innovative activities in the context of which it is defined as "a set of knowledge and skills in the emotional, intelligent work, ability to identify targets cognitive activity plan, perform cognitive operations in various ways to work with sources draw conclusions, summarizing information, develop emotional intelligence" [6]. Thus, the intellectual culture characterizes the development of intellectual abilities needed to perform cognitive activity.

The issue of establishing a new intellectual culture through the introduction of new educational technologies was raised by us earlier [7]. We believe that the intellectual culture should be considered as integrity of human life, not limiting it purely cognitive (scientific and cognitive or educational) activities. Man is a thinking being in all spheres of life. In this meaning, the intellectual culture above all is part of the individual culture and determines the nature of human relations, not only in the professional sphere, but also in the organizing of their own lives, in the development of abilities and needs of intelligent attitude. It is no accident attention in the analysis of intellectual culture given to emotional intelligence (EQ), which is associated with such basic human abilities like selfesteem, self-control, motivation, empathy, tolerance, dialogic and others. In particular, the American psychologist D. Goleman emphasizes academic knowledge that does not prepare us for trouble or failures, or life opportunities. At the same time emotional intelligence is essential to understanding how our fate was formed, how successful we will cease to suffer from internal battles. "Managing emotions - it meta-ability that determines how well we can use our skills and abilities, including those mental abilities that have not "polished" [8, pp. 80-81]. In fact, D. Goleman considers emotional intelligence as an important personal value factor in the formation and selfdetermination rights.

It can be claimed that due to emotional intelligence intellectual culture takes personal dimension, "reveals its dependence on the human ability to perceive, identify, understand emotions and feelings (own and others), manage them, in general, that is a prerequisite for facilitation of thinking" [6]. Looking ahead, we note that among the competencies that graduates must master the modern university emotional intelligence ranks the sixth place among the ten positions of "soft skills".

It is necessary to highlight, perhaps, the most important aspect in understanding intellectual culture - it generates creative ideas and knowledge, it is responsible not only for updating the information society, but also value content knowledge. Actually, creativity distinguished intellectual culture of intellectual activity, as it involves absorption of knowledge in the process of improvement of man's life world. The new intellectual culture, thus requiring new educational practices centered - a person who creates and who is able to direct their thoughts, knowledge and action in self-development in organic unity with the world. Creating intellectual capital is possible by creating cultural (value) in the context of education.

It is obvious that education fulfills a crucial role in the formation of intellectual culture. It creates conditions for the formation of a wide range of specialist skills (that is, 
the one that owns the "multi-skills-profile"), "ready to learn always and everywhere" [9, p. 76]. There is development of "pervasive" (a cross-cutting education), or "continuous" ("life-long learning") education, and teachers and students should actively and flexibly respond to changes in all spheres of society [9, p. 78]. The issue of education, therefore, the issue of scientific and educational practices on which the focus, is not on what to teach but on how to teach [9, p. 57]. Ways and means of solving it determine what will be the emerging intellectual culture of the future. General issues, which are examined, may be specified in the analysis of the problem of training modern managers.

Search query on the modernization of the educational process of higher education in Ukraine requires effective use of modern educational technologies. Here are the criteria that we believe must meet effective humanitarian educational technology today: the criterion of intensification of knowledge during the education process in classroom (lectures, seminars, workshops, etc.), the criterion of minimizing search and information operations of the students outside of the classroom; criterion of deepening of analytical component of the educational process, criteria of directional interaction "student - teacher" on the formation of the planned competence. Particular attention is paid to the problem of informed decision outcomes of the course the students study. Taking into consideration our own experience, it should be noted that more efficient is provided when students are aware and they work on the individual agreement to achieve quality indicators of intellectual culture.

To search pedagogical techniques that facilitate mastery of "soft skills" competencies, Department of Philosophy of the National University "Odessa Maritime Academy" in 2018 began work on the interdisciplinary project "Co-generative knowledge: humanism, innovation, selfeducation." The project plans to explore and implement the international and domestic experience at universities as for forming the intellectual culture of future specialists. Particular, the transformation of educational programs in accordance with the international project "Education2030", which focuses on the system of competences within the triad "knowledge - skills - values". Declaring OECD principles of teaching-2030, the authors (Andreas Shleicher and others) note that future professionals must first "learn to be systemic thinkers" [10, p. 28].

The concept of «co-generative knowledge» that becomes a means of intellectual culture, the main cogenerative marker's, co-creation, in our opinion, have a common "design" frame knowledge dyad "student teacher". This significantly changes the role of the teacher who models, initiates and directs the co-creation, coproduction effects. From the broadcast of a pyramidal system of organized knowledge, it goes to the design and facilitation of co-generation effects, creating an "open knowledge". Under the terms of an international instrument called the European Constitution Education (Pedagogical Constitution of Europe, 2013) it is declared the current role of the teacher - as a "specialist in the actual transfer of basic and specialized knowledge and techniques of mastery over life". We emphasize that the emphasis in the new educational technologies is on selfdevelopment ability (LLL-technology). We believe that forming of self-educational abilities of humans, no doubt, based on the developed intellectual culture.

The problem of an efficient transfer of educational and professional skills discussed in the scientific community is quite active, for example, the three stages George Basalla's model of scientific knowledge distribution is currently spread. A. Skott-V. Saymon and Reed-Brown paint the process of innovative knowledge transfer, which, in their opinion, provided by the system members: the generators of knowledge - knowledge transfer from experts those who should provide knowledge [11]. However, the concept of "basic knowledge transfer" is not reasonably sufficient. The most significant role in the transfer of fundamental knowledge belongs to a philosophy teacher; because he/she can identify prospects for future demand for certain spiritual values and draws them using the funds of cultural era. That is the future value to specialists in management, in our view, namely, to obtain intellectual competence culture.

Thus the education system is moving from traditional teaching technologies of knowledge (through its accumulation on the principle "from simple to complex") to better information space in excessive transfer of technology "frame of knowledge". The term "frame" that once was offered in engineering of knowledge by Marvin Minsky [12], seems most apt to demonstrate the potential of structuring new knowledge. Target sets for the formation of frames appear in the process of decisions making by the audience while completing some challenges.

First, we note that the transfer technology framelearning differs with a more thorough study of meaning combination of material that is updated with its practical component. That building of frame particles enhances not just accumulation of material and facts, but its procedural essence, focus on the "knowledge how". The minimum unit of the cognitive learning process is not a topic of curriculum and educational frame. We consider educational frame as a circle of related problems that reveal the essence of the section of the course and have the target set for the formation of a particular value and ability of higher education applicant. The skill of the teacher in possession of new technology is resulting in effective combination of content and saturation of philosophical problem that under consideration and value-target setting that is forming during teaching the subjects, for instance, "Philosophy", "Logics" etc.

Secondly, transfer technology of frame-learning has the difference in space-time construction. Namely, in our view, it is appropriate to separate the different levels of interaction in the "student-teacher" system in spatial sense. Let us explain this position with a specific example. Philosophy courses for our students-managers consist of five educational frames. Each frame combines education related philosophical problems. In temporal aspect, it may include four or five lectures and two or three seminars that range from twelve to sixteen hours. According to the new technology at every level of interaction with the student, the teacher has designed various quality educational outcomes.

The first level of interaction that is carried out at the first lecture the teacher leads the formation of information and cognitive attractor. In particular, he/she more actively encourages primary interest in the exploration of the set 
of problems. To do this, he/she needs to find information on the problem that the audience already has, then to find out who is a leading carrier of deeper awareness and are interested in or have experience in dealing with the problems outlined. Priority actions of the teacher - information saturation range of problems. Key educational technologies are: a review of heuristic program in interactive mode, interactive group discussion, and creative formation of groups of students in terms of cognitive activity.

The second level of interaction that occurs more active in the second - the third lecture and the first workshop, the teacher conducts theoretical conclusions and generalizations of heuristic correction of educational material with a reference to individual cognitive activity of the group. From the teacher's side the navigation service dominates in the information space, promotion of independent work of students from different sources of information under the control of the teacher, motivational enhancement component of the process. Key educational technology at the second level of interaction: Workshop "immersion in the problem," the use of case studies, individual and group (group of no more than 2-4 people) simulation training tasks at this stage is already possible to connect students from the mutual control (control and test pair work, or report a leading connoisseur). As shown in the author's practice, pedagogical control at the second level is not effective.

At the third level (last lectures and seminars frame) the integrated search of information and analytical work to achieve a quality result of knowledge becomes important. The teacher can use combined, flexible technology, namely the free choice of reporting forms (group discussion, role-play, individual analysis of mind maps presented on individual achievements such as Pecha-Kucha). It is not rating system, but the system of rewards and encouragement in various ways has been demonstrated in the classroom its effectiveness. A Leader-expert can switch to a new status of "instructor solving specific problems," students who were more active in individual work are "titled" as the firewall (defender) of the range of the solutions. It is better, in our view, if the teacher can use elements of intelligent humor.

In the process of completion and summarizing of the quality of knowledge on problems mastering of educational frame, the vital efficiency is a combination of two educational methods: monitoring student achievement and educational tool feedback (or add-in return) with the construction of mental maps.

Monitoring of educational achievement of the student is introduced by the teacher in the first (introductory) lesson and conducted throughout the course clearly. The students are offered two documents: the first - an educational "road map" of the course, which includes the date and theme lectures and seminars, and methods of their implementation; reporting forms for the students. The second document the student has to fill in during the whole cycle - a personal 'roll of success' of the student, which provided all kinds of work of the course (lectures, seminars, independent and collective responses, participation in discussions, written work, final tests, individual assignments, etc.) and the corresponding number of points for each item of the information. Thus, the student is planning their own future results, based on the final regular forms of individual learning paths. Teacher monitors, stimulates and corrects personal learning track of each student. When a student lags far behind the proposed "road map" of the course, the teacher must notify him/her about the regime change planning. This is - mode "with the aggravation" - a learning style and time should be redistributed more effectively to achieve the best possible results from the course.

Methods of the feedback (or add-in return) seems very effective in the situation of a limited number of hours of the course, as an alternative to traditional test problems. Often it is used in cases where it is necessary to conduct quick snapshot of students' knowledge and add a note of creativity in the learning process. For a more detailed survey of each student in the group on the results of the study of a section, it is effective to use mental maps (mind maps). In the process of constructing mental maps frame student carries out a repetition of themes, summarizes the ideas used by adding them to a single picture of the perception of the discipline.

We shall note that the basic educational technology at the third level of interaction in the "student-teacher" system should form stable cognitive motivated interest in philosophical problems together with meta-cognitive productive skills training. We specify that this is a mainstream concept of co-generative knowledge; it aims to formation of cognitive and meta-cognitive skills of future professional managers. Specialists in management education of the future state the fact that meta-cognitive teacher training strategy is implemented together with the students, because it is the student - not passive one, but active integrator of meta-cognitive classroom practices [13]. According to Catherine Hall Shtenher who is investigating cognitive passive and proactive cognitive learning strategies, markers of the first variant should be the statements: "I have read, reviewed the topic material; the definition provided in the text ", etc. Markers of the proactive option, i.e., those ones that are later converted into metacognitive strategy are: "I have written questions to the text; Why was it made such a conclusion; How this conclusion may be attributed to the overall picture of knowledge?" [14].

The idea of directional engineering knowledge has been implemented by the group led by Peter Senge Mike - Director of Center for Organizational Learning at School of Management at the Massachusetts Technological University. The Five-elements model of "a learning organization" seems interesting because it captures the attention of a special ability as the individual and social groups (e.g., labor groups) to successful, competitive survival in the future. These skills, according to P. Senge, include: skills of self improvement, overall constructive vision (analytical ability), group dialog learning, systems thinking and predictive modeling [15].

Conclusions. Today is clear that innovative changes in socio-cultural nature cannot leave without attention educational environment of high school as well. That teacher should be a pioneer-converter to produce co-generative knowledge. The teacher has to implement new educational practices aimed at enhancing the intellectual independence of young people, their social responsibility, conscious citizenship, and democratic choice for themselves 
and their country. The realities of today need to model and implement such educational technologies that contribute to the cultural content of scientific and educational space, updating the intellectual potential of the modern manager. Target set of such models is to achieve personal growth as in a professional field and outside of it - in the practice of human life. In a democratic society the need for new managers who are intellectually independent, possess critical thinking, human values is greatly increased. The new intellectual culture makes demands to the modern culture of management and organizational culture. In the foreground - co-generation human potential and human activity, understanding and implementation of which is the main task of every thinking person.
1. Willcoxson L., Millett B. The Management Of Organisational Culture, Australian Journal of Management \& Organisational Behaviour, Vol. 3, No. 2, 2000, p. 96.

2. Журавльов В.M. Взаємозв'язок типів менеджменту та корпоративної культури. [in:] Наукові праці КНТУ. Економічні науки, 2010, вип. 17, p. 331-336. zations: Software of the Mind: Intercultural Cooperation and Its Importance for Survival, 3rd Edition, McGraw-Hill USA, 2010, p. 6.

4. Donnikova I. A. Moral search in multicultural communication [in:] Anthropological measurements of philosophical research, No 14 (2018), p. 30-41, DOI: https://doi.org/10.15802/ampr.v0i14.150545.

5. Доннікова I.А. Культура і людина в онтології становлення [in:] Гуманітарний вісник Запорізької державної інженерної академії, випуск 60,2015 , с. 63-72, DOI: https://doi.org/10.30839/2072-7941.2015.42590.

6. Драган О. І. Інтелектуальна культура як складова інноваційної культури для інноваційного розвитку організації [in:] Економіка ринкових відносин, 2013, №. 11, с. 251 258, http: // dspace.nuft.edu.ua/jspui/handle/123456789/8735, (access: 21.04.2019)

7. Донникова И. А. Научно-образовательные сообщества как форма интеллектуальной культуры [in:] Пере-пост, 2019,
3. Hofstede G., Hofstede G.J., Minkov M. Cultures and Organi$\begin{array}{lcr}\text { № } & 5, & \mathrm{http} / / \text { www.philosophy- } \\ \text { multidimensionality.com/index.php/component/content/articl }\end{array}$ e?id=341 (access: 05.04.2019)

8. Гоулман Д. Емоційний інтелект. Х.: Віват, $-2018,-512$ с.

9. Моравец, Джон У., Общество Знаниевых Кочевников, Томск, Издательский Дом Томского государственного университета, $-2018,-346$ с.

10. Діяльність ОЕСР. Освіта й компетентності [in:] Вісник TIMO, 2018, № 02-03, c. 12-58.

11. Pedagogical Constitution of Europe.

12. Минский М.Л. Сообщество раз ума, М.: Изд-во АСТ, 2018, $592 \mathrm{c}$.

13. Tanner Kimberly D. Promoting Student Metacognition CBE Life - Sciences Education, Vol. 11, No. 2 Published Online: 13 Oct 2017. Retrieved from: https://doi.org/10.1187/cbe.1203-0033 Date 04/11/2019 appeal.

14. Shtenher Hall C. Author's page on the Web. Retrieved from: http://www.plantbio.uga.edu/directory/people/kathrin-fstanger-hall. Date 04/11/2019 appeal.

15. Сенге П. П'ята дисципліна: мистецтво та практика організації, котра самонавчається. К.: Олімп-Бізнес, 2011,408p. https://books.google.com.ua/books?id=tklBDAAAQBAJ\&pg (access: 18.03.2019)

\section{REFERENCES}

2. Zhuravlev V. Relationship types of management and corporate culture, Proceedings KNTU. Economics, 2010, vol. 17, pp. 331-332.

5. Donnikova I.A. Culture and people in the ontology of becoming, Journal of Humanities Zaporizhia State Engineering Academy Issue 60, 2015, p 64.

6. Dragan A.I. Intellectual culture as a part of the innovation culture for innovation development organization, Economy Market Relations, 2013, No. 11. Retrieved from: http://dspace.nuft.edu.ua/jspui/handle/123456789/8735.

7. Donnykova I.A. Scientific and educational the Community As a form of intellectual culture, Re-Post, 2019, No.5. Retrieved from: http:// www.philosophy-multidimensionality.com/ index.php/component/content/article?id=341.

8. Goleman D. Emotional Intelligence. Kharkov: Vivat, 2018, 512, pp. 80-81.
9. John W. Moravian, Knowmad Society, Tomsk, Tomsk Home Publishing of the State University, 2018, p. 76.

10. Activities of OECD. Education and competence, TIMO Bulletin, 2018, No.02-03, p. 28.

12. Minskij M.L. The Community once the mind, M.: AST Publishing House, 2018, 592 p.

13. Tanner Kimberly D. Promoting Student Metacognition CBE Life - Sciences Education, Vol. 11, No. 2 Published Online: 13 Oct 2017. Retrieved from: https://doi.org/10.1187/cbe.1203-0033 Date 04/11/2019 appeal.

14. Shtenher Hall C. Author's page on the Web. Retrieved from: http://www.plantbio.uga.edu/directory/people/kathrin-fstanger-hall. Date 04/11/2019 appeal.

15. Senge P. The Fifth Discipline: The Art and Practice organization that self-learning. K.: Business-Olympus, 2011, 408 p. Retrieved from: https://books.google.com.ua/books?id=tklBDAAAQBAJ\&pg 